\title{
STUDI ISOLASI DAN RENDEMEN LIGNIN DARI TANDAN KOSONG KELAPA SAWIT (TKKS)
}

\author{
Harmaja Simatupang, Andi Nata, Netti Herlina \\ Departemen Teknik Kimia, Fakultas Teknik, Universitas Sumatera Utara \\ Jln. Almamater Kampus USU, Medan 20155, Indonesia \\ E-Mail: majasimatupang@yahoo.com
}

\begin{abstract}
Abstrak
Tandan kosong kelapa sawit (TKKS) merupakan salah satu limbah padat yang dihasikan oleh industri perkebunan kelapa sawit yang banyak mengandung serat. Ditinjau dari komposisi kimianya, TKKS mempunyai potensi untuk digunakan sebagai sebagai sumber bahan kimia yaitu lignin. Lignin dapat dimanfaatkan secara komersial sebagai bahan pengikat, perekat, pengisi, surfaktan, produk polimer, dispersan dan sumber bahan kimia lainnya. Penelitian ini menggunakan serbuk serat TKKS yang telah dibersihkan dari zat ekstraktif dengan mengekstraknya menggunakan benzene : etanol $96 \%(2: 1, v / v)$ selama 6 jam. Serbuk serat ini kemudian dimasak dengan variasi pemasakan 1,2,3 jam dengan variasi penambahan $\mathrm{NaOH}$ 10\%,15\%,dan 20\% sehingga diperoleh lindi hitam, dan variasi pengenceran lindi hitam pada saat isolasi lignin. Hasil penelitian menunjukkan rendemen lignin optimum yang diperoleh yaitu 16,42\% dengan kemurnian lignin 84,21\% pada perlakuan pemasakan 2 jam dengan penambahan $\mathrm{NaOH} 20 \%$ dan proses pengenceran lindi hitam 1:2. Hasil uji FT-IR menunjukkan lignin mempunyai panjang gelombang gugus fungsi penyusun yang sesuai dengan lignin standar.
\end{abstract}

Kata Kunci: tandan kosong kelapa sawit (TKKS), lignin, isolasi lignin, rendemen

\begin{abstract}
Oil palm empty fruit bunches (TKKS) is one of the solid waste generated by the palm oil industry that contain lots of fiber. Based from its chemical composition, TKKS has the potential to be used as a source of chemicals that lignin. Lignin can be used commercially as binders, adhesives, fillers, surfactants, polymer products, dispersants and other chemicals. This study used fiber powder TKKS cleared of extractive substances to extract them using benzene: $96 \%$ ethanol $(2: 1, v / v)$ for 6 hours. Fiber powder is then cooked with a variety of cooking 1,2,3 hours with the addition of $\mathrm{NaOH}$ variation of $10 \%, 15 \%$, and $20 \%$ to obtain the black liquor, black liquor and dilution variations during lignin isolation. The results showed that the optimum yield of lignin obtained is $16.42 \%$ with $84.21 \%$ purity lignin in cooking 2 hour treatment with the addition of $20 \% \mathrm{NaOH}$ and diluting the black liquor 1:2. The test results showed FT-IR has wavelengths lignin constituent functional groups in according with the standard lignin.
\end{abstract}

Keywords: oil palm empty fruit bunches, lignin, lignin isolated, yield

\section{Pendahuluan}

Menurut Direktorat Jenderal Perkebunan Perkelapa Sawitan Indonesia luas area perkebunan kelapa sawit di Indonesia terus mengalami peningkatan sejak tahun 1999 hingga tahun 2006 dan terus mengalami peningkatan setiap tahunnya. Hal tersebut terbukti dari data Dirjen Perkebunan (2005) yang menunjukkan bahwa luas areal perkebunan besar kelapa sawit selama delapan tahun terakhir (2000-2007) terus mengalami peningkatan. Hal tersebut secara lansung berpengaruh pada limbah padat yang dihasilkan industri minyak kelapa sawit yaitu tandan kosong kelapa sawit (TKKS) juga mengalami peningkatan [4].

Pemanfaatan TKKS yang umum dilakukan saat ini adalah digunakan sebagai mulsa di kebun, akan tetapi biaya transportasi yang dikeluarkan per unit cukup tinggi. Pemanfaatan lainnya adalah sebagai bahan baku dalam pembuatan pupuk organik. TKKS dalam pemanfaatannya dibakar di incenerator sehingga abunya dapat digunakan sebagai pupuk kalium. Namun usaha pembakaran TKKS tersebut temyata tidak efektif dan dilarang oleh pemerintah karena dapat menimbulkan pencemaran udara [3]. Ditinjau dari komposisi kimianya, TKKS mempunyai potensi untuk digunakan sebagai sebagai sumber bahan kimia yaitu lignin. Lignin dapat dimanfaatkan secara komersial sebagai bahan pengikat, perekat, pengisi, surfaktan, produk polimer, dispersan dan sumber bahan kimia lainnya [5]. Sehingga perlu diketahui kondisi proses isolasi lignin dengan rendemen terbaik pada lingkup penelitian.

Manfaat dari penelitian yang dilakukan adalah dapat memberikan pengetahuan pada peneliti serta masyarakat umum tentang rendemen 
lignin pada proses isolasi lignin yang optimum pada rentang ruang lingkup variasi penelitian yang dilakukan.

\section{Tinjauan Pustaka}

Tandan kosong kelapa sawit (TKKS) adalah limbah padat yang dihasilkan oleh pabrik minyak sawit mentah atau Crude Palm Oil (CPO). Dalam satu hari pengolahan bisa dihasilkan ratusan ton TKKS. Komponen utama TKS adalah selulosa, hemiselulosa, dan lignin.

Lignin merupakan komponen makro molekul kayu ketiga yang berikatan secara kovalen dengan selulosa dan hemiselulosa. Struktur molekul lignin terdiri atas sistem aromatik yang tersusun atas unit-unit fenil propana. Lignin dapat dibagi menjadi beberapa kelas menurut unsur-unsur strukturnya yaitu lignin guaiasil (terdapat pada kayu lunak sebagian besar merupakan produk polimerisasi dari koniferil alkohol), dan lignin guaiasil-siringil (khas kayu keras merupakan kopolimer dari koniferil alkohol dan sinapil alkohol) [5].

Lignin umumnya tidak larut dalam pelarut sederhana, namun lignin alkali dan lignin sulfonat larut dalam air, alkali encer, larutan garam dan buffer. Terdapat beberapa metoda pengisolasian lignin dari serat TKKS, yaitu secara kimiawi dan enzimatik. Mengingat metoda isolasi lignin secara enzimatik mahal pada biaya produksi dan lamanya proses produksinya, maka metoda isolasi lignin secara kimiawi dipilih. Lignin dari serat TKKS dapat diisolasi melalui proses delignifikasi, yaitu proses pelarutan lignin (pulping).

Proses delignifikasi terdiri dari proses mekanis, semi kimia, kimia (alkali, sulfat/kraft, sulfit) dan proses non konvensional yang lebih berwawasan lingkungan. Pada kenyataannya, proses pulping secara konvensional tersebut memiliki beberapa kelemahan, terutama terhadap rendemen pemasakan yang rendah, biaya produksi tinggi, laju delignifikasi rendah dan pencemaran lingkungan karena adanya limbah larutan pemasak.

Lignin larut dalam pelarut organik didasarkan pada perbedaan kelarutan komponen kimia bahan baku pulp, dimana lignin dan ekstrakstif larut dalam pelarut organik, karbohidrat dengan bobot molekul rendah dapat larut dalam air sedangkan selulosa tidak larut dalam kedua larutan tersebut. Delignifikasi pada proses organosolv disebabkan oleh terputusnya ikatan eter, yaitu $\alpha$-aril eter $(\alpha-\mathrm{O}-4)$ dan aril gliserol- $\beta$-aril eter $(\beta-\mathrm{O}-4)$ dalam molekul lignin [8]. Hal tersebut merupakan dasar dalam proses pulping organosolv.

\section{Metodologi Penelitian}

Penelitian ini dilakukan dengan beberapa tahapan yaitu persiapan bahan baku serat tandan kosong kelapa sawit (TKKS), pembuatan serpihan TKKS bebas zat ekstraktif, delignifikasi serpihan TKKS, isolasi lignin dari lindi hitam TKKS, menghitung nilai rendemen lignin, dan uji gugus fungsi pada lignin dengan menggunakan FT-IR.

Tahapan persiapan bahan dilakukan dengan TKKS dibersihkan dari sisa kulit buah sawit, kemudian diuraikan menjadi bentuk serat dan dikeringkan di udara terbuka (sinar matahari) selama satu minggu. Serat TKKS yang telah kering dipotong dengan ukuran panjang $\pm 30 \mathrm{~mm}$. Serat tersebut kemudian digiling menggunakan mesin penggiling (ball mill). Lalu serbuk yang terbentuk diayak dengan saringan mesh ukuran 50. Serbuk yang terbentuk dikeringkan pada oven pada suhu $60{ }^{0} \mathrm{C}$ hingga berat serbuk konstan.

Serbuk yang telah dikeringkan lalu diekstraksi dengan menggunakan dengan menggunakan benzene : etanol $96 \%(2: 1, \mathrm{v} / \mathrm{v})$ selama 6 jam pada soxhlet apparatus. Residu hasil pengeringan oven tersebut diekstraksi kembali dengan menggunakan air pada suhu 100 ${ }^{0} \mathrm{C}$ selama 1 jam sehingga didapatkan serpihan TKKS yang bebas zat ekstraktif.

Serbuk TKKS yang bebas zat ekstraktif dimasukkan pada digester dengan penambahan larutan pemasak pada pernbandingan $10: 1(\mathrm{v} / \mathrm{b})$, dimana komposisi larutan pemasak adalah etanol 96\% : air (1:1). Pada digester ditambahkan katalis $\mathrm{NaOH} 10$, 15, dan $20 \%$ dari berat bahan baku. Campuran kemudian dimasak pada digester pada suhu $170{ }^{\circ} \mathrm{C}$ dengan variasi pemasakan 1,2 , dan 3 jam sehingga diperoleh lindi hitam (lignin terlarut).

Dilakukan penyaringan dengan menggunakan kain. Kemudian dilakukan pengenceran lindi hitam : air dengan variasi perbandingan pengenceran 1:1, 1:2, 1:3. Lindi hitam yang telah disaring (filtrat) diendapkan ligninnya dengan cara titrasi oleh asam $\left(\mathrm{H}_{2} \mathrm{SO}_{4}\right)$ dengan konsentrasi $20 \%$ sampai $\mathrm{pH} 2$ sambil dilakukan pemanasan pada suhu $60{ }^{0} \mathrm{C}$ sambil diaduk cepat dengan magnetic strirer, kemudian didiamkan minimal selama 8 jam agar pengendapan sempurna. Endapan lignin dipisahkan dari lindi hitam yang telah diasamkan dengan menggunakan alat sentrifuse $(4500 \mathrm{rpm}$, 20 menit). Untuk meningkatkan kemumian lignin, endapan lignin tersebut dilarutkan kembali dengan $\mathrm{NaOH} 1 \mathrm{~N}$, kemudian larutan lignin diendapkan kembali dengan cara titrasi menggunakan asam sulfat $\left(\mathrm{H}_{2} \mathrm{SO}_{4}\right)$. Endapan lignin dipisahkan kembali dengan menggunakan alat sentrifuse, kemudian disaring dengan kertas saring sehingga dihasilkan larutan lignin dengan kemurnian yang lebih tinggi. Selanjutnya endapan 
dicuci menggunakan $\mathrm{H}_{2} \mathrm{SO}_{4} \quad 0,01 \mathrm{~N}$, dilanjutkan pencucian dengan aquades dan disaring menggunakan penyaring vakum. Endapan yang telah dicuci dikeringkan dalam oven $\left(50-60{ }^{\circ} \mathrm{C}\right)$ selama 24 jam sampai berat konstan sehingga dihasilkan lignin berbentuk serbuk tepung.

Rendemen lignin dihitung berdasarkan perbedaan berat antara lignin yang diperoleh setelah dikeringkan dengan berat serpih TKKS yang digunakan. Rendemen dinyatakan dalam bentuk persen berat (gram) per berat serpih TKKS $(\% \mathrm{~b} / \mathrm{b})$

\section{Hasil dan Pembahasan}

Hasil pengukuran rata-rata rendemen isolat lignin yang dihasilkan dari delignifikasi serbuk tandan kosong kelapa sawit pada penelitian ini berkisar antara $6,85 \%$ sampai $16,42 \%$ berat kering serpih. Adapun nilai rendemen lignin terendah yaitu $6,85 \%$ pada isolat lignin dengan perlakuan pemasakan 1 jam dengan penambahan katalis $\mathrm{NaOH} 10 \%$ dan proses pengenceran lindi hitam 1:1. Sedangkan nilai rendemen lignin tertinggi yaitu $16,42 \%$ pada isolat lignin dengan perlakuan pemasakan 2 jam dengan penambahan katalis $\mathrm{NaOH} 20 \%$ dan proses pengenceran lindi hitam 1:2.

Hubungan antara Waktu Pemasakan terhadap Rendemen Lignin

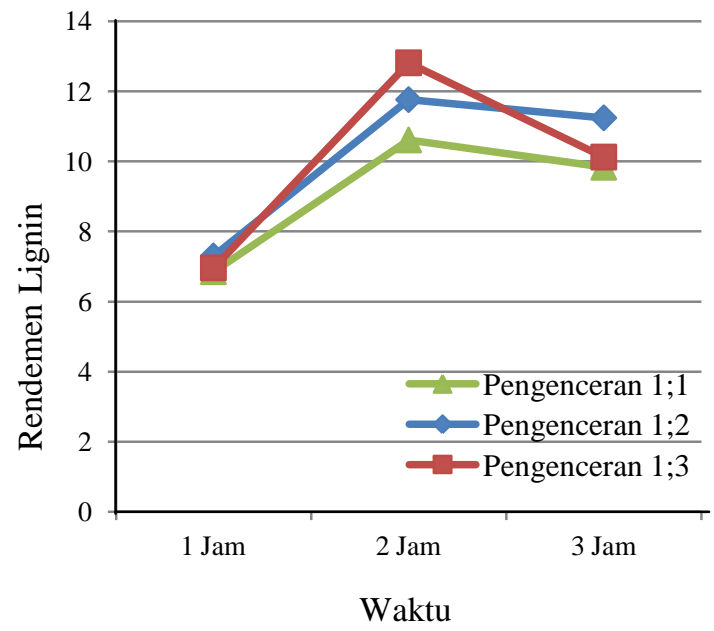

\section{Gambar 1. Hubungan antara Waktu Pemasakan terhadap Rendemen Lignin}

Grafik di atas menunjukkan hubungan antara waktu dan pemasakan lindi hitam tandan kosong kelapa sawit (TKKS) terhadap rendemen lignin yang dihasilkan. Dari grafik di atas dapat dilihat bahwa secara umum terjadi peningkatan kadar rendemen lignin pada rentang waktu 1 jam sampai 2 jam, namun terjadi penurunan pada rentang waktu 3 jam. Nilai rendemen lignin pada pengenceran 1:1 saat waktu 1 jam yaitu $6,85 \%$, meningkat menjadi $10,61 \%$, dan terjadi penurunan pada waktu 3 jam menjadi $9,83 \%$.

Semakin bertambahnya waktu pemasakan akan mempengaruhi proses delignifikasi. Dimana peningkatan waktu pemasakan akan meyebabkan lignin yang terlarut akan semakin banyak dan proses impregnasi antara pelarut dengan serbuk TKKS semakin sempurna (Sjostrom, 1995). Namun pada waktu pemasakan yang cukup lama akan memicu terjadinya degradasi senyawa penyusun lignin yang menyebabkan menurunnya rendemen yang diperoleh.

Hubungan antara Konsentrasi $\mathrm{NaOH}$ terhadap Rendemen Lignin

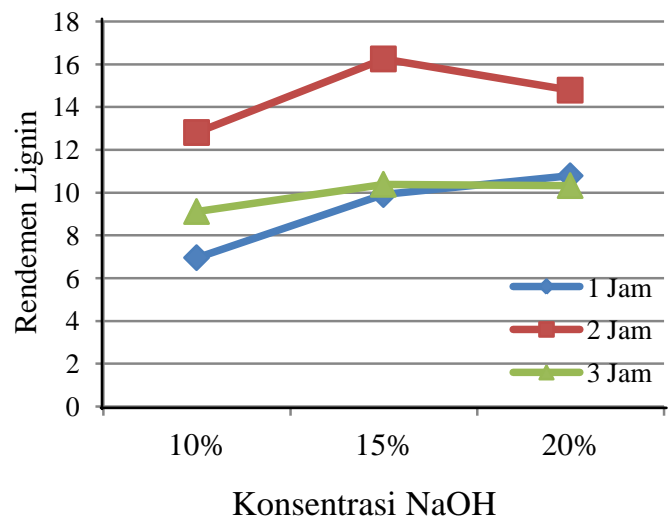

\section{Gambar 2. Hubungan antara Konsentrasi $\mathrm{NaOH}$ terhadap Rendemen Lignin}

Grafik di atas menunjukkan hubungan antara konsentrasi $\mathrm{NaOH}$ pada saat pemasakan lindi hitam tandan kosong kelapa sawit (TKKS) terhadap rendemen lignin yang dihasilkan. Berdasarkan grafik di atas terjadi peningkatan rendemen lignin seiring dengan meningkatnya konsentrasi katalis $\mathrm{NaOH}$ pada waktu pemasakan. Peningkatan rendemen lignin terjadi baik pada waktu pemasakan 1 jam dimana rendemen lignin meningkat dari $6,69 \%$ pada $\mathrm{NaOH} 10 \%$ menjadi 9,91\% pada $\mathrm{NaOH} 15 \%$ dan 10,79 pada $\mathrm{NaOH}$ $20 \%$. Namun pada pemasakan 2 dan 3 jam terjadi peningkatan kadar lignin seiring meningkatnnya $\mathrm{NaOH}$ namun turun pada konsentrasi $\mathrm{NaOH} 20 \%$.

Menurut Damat (1989), peningkatan konsentrasi $\mathrm{NaOH}$ memudahkan pemutusan ikatan senyawa penyusun lignin sehingga lignin lebih mudah dilarutkan pemasak, yang menyebabkan peningkatan padatan total pada lindi hitam tersebut sehingga kadar rendemen lignin pun meningkat. Terjadinya penurunan kadar rendemen lignin ini diduga karena pada konsentrasi $\mathrm{NaOH}$ yang lebih tinggi akan menyebabkan perusakan senyawa lignin yang menyebabkannya ikut terlarut pada pelarut. 
Hubungan antara Pengenceran Lindi Hitam terhadap Rendemen Lignin

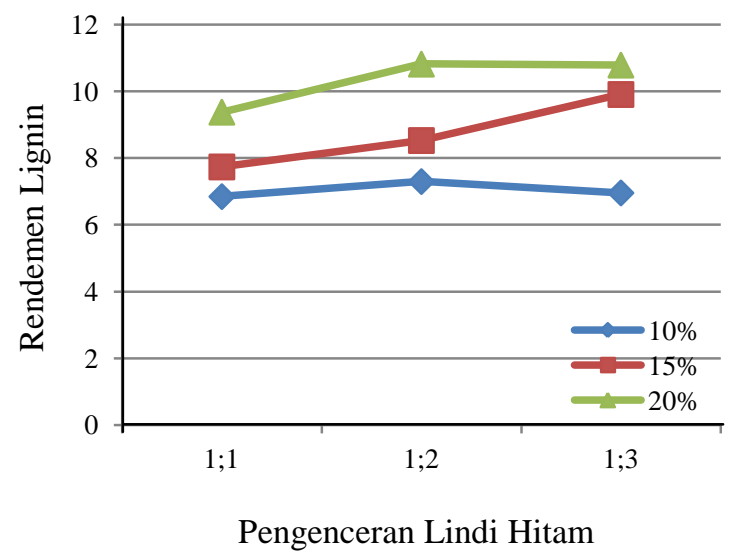

Gambar 3. Hubungan antara Pengenceran Lindi Hitam terhadap Rendemen Lingin

Dari grafik di atas dapat dilihat bahwa terjadi peningkatan kadar lignin seiring dengan peningkatan pengenceran lindi hitam yang dilakukan pada penggunaan katalis $\mathrm{NaOH} 15 \%$, pada pengenceran lindi hitam 1:1 kadar lignin yg diperoleh 7,74 meningkat menjadi 8,53 pada pengenceran lindi hitam 1:2 dan pada pengenceran lindi hitam 1:3 menjadi 9,91\%. Namun terjadi penurunan kadar lignin pada saat pengenceran lindi menjadi 1:3 walaupun penurunannya tidak terlalu signifikan.

Pengenceran lignin ini akan menurunkan konsentrasi lindi hitam yang akan dititrasi/ditambahkan dengan $\mathrm{H}_{2} \mathrm{SO}_{4}$ untuk mengkondensasi senyawa lignin tersebut. Menurut Achmadi (1990), pada suasana asam lignin cenderung melakukan kondensasi sehingga pada saat pengendapan dilakukan semakin banyak lignin yang terisolasi. Penambahan asam yang terlalu kuat pada larutan sisa pemasak (lindi hitam) meyebabkan terjadinya degradasi polisakarida dan dekomposisi komplek ligninkarbohidrat.

\section{Uji FT-IR Senyawa Lignin}

Salah satu cara analisa untuk mengetahui keberhasilan isolasi lignin adalah dengan mengidentifikasi gugus fungsi yang ada. Analisa ini dilakukan dengan alat FT-IR yang mampu mengidentifikasi serapan-serapan khas untuk masing-masing gugus fungsi yang terkandung dalam sampel.
Tabel 1. Bilangan Gelombang Gugus Lignin [6]

\begin{tabular}{|c|c|l|}
\hline $\begin{array}{c}\text { Bil.Gelombang } \\
\left(\mathrm{cm}^{-1}\right) \text { Pada } \\
\text { Penelitian }\end{array}$ & $\begin{array}{c}\text { Standar } \\
\text { Kisaran } \\
\text { Pita Serapan }\end{array}$ & \multicolumn{1}{|c|}{$\begin{array}{c}\text { Keterangan } \\
\text { Gugus } \\
\text { Fungsi }\end{array}$} \\
\hline 3414.00 & $3400-3450$ & Uluran O-H \\
2939,52 & $2820-2940$ & Uluran C-H metil \\
1633,71 & $1600-1610$ & Cincin Aromatik \\
1506,41 & $1505-1515$ & Cincin Aromatik \\
1468,18 & $1460-1470$ & C-H Asimetri \\
1319,31 & $1330-1315$ & Cincin Siringil \\
1278,81 & $1270-1280$ & Cincin Guaiasil \\
1060,85 & $1030-1085$ & Uluran Eter \\
862,18 & $850-875$ & C-H aromatik \\
\hline
\end{tabular}

Menurut Hergert (1971), senyawa lignin secara umum diidentifikasi dengan munculnya beberapa gugus penyusun seperti serapan pada bilangan gelombang $3400-3450 \mathrm{~cm}^{-1}$ untuk regang $\mathrm{OH}, 2820-2940 \mathrm{~cm}^{-1}$ untuk regang $\mathrm{C}-\mathrm{H}$ metil, 1600-1515 $\mathrm{cm}^{-1}$ untuk cincin aromatik, $1460-1470 \mathrm{~cm}^{-1}$ untuk regang $\mathrm{C}-\mathrm{H}$ asimetri, 1330 $1315 \mathrm{~cm}^{-1}$ untuk regang cincin stringil, $1270-1280$ $\mathrm{cm}^{-1}$ untuk cincin guasil, $1030-1085 \mathrm{~cm}^{-1}$ untuk regang eter dan $850-875 \mathrm{~cm}^{-1}$ untuk $\mathrm{C}-\mathrm{H}$ aromatik.

Berdasarkan gambar grafik FT-IR pada rentang bilangan gelombang antara $400-4000 \mathrm{~cm}^{-}$ 1 dan dengan membandingkan gugus senyawa lignin standar dan pada penelitian di atas dapat dilihat bahwa telah sesuai dan relevan dengan gugus umum yang terdapat dalam lignin. Sehingga dapat disimpulkan bahwa senyawa tersebut memang benar-benar lignin. 


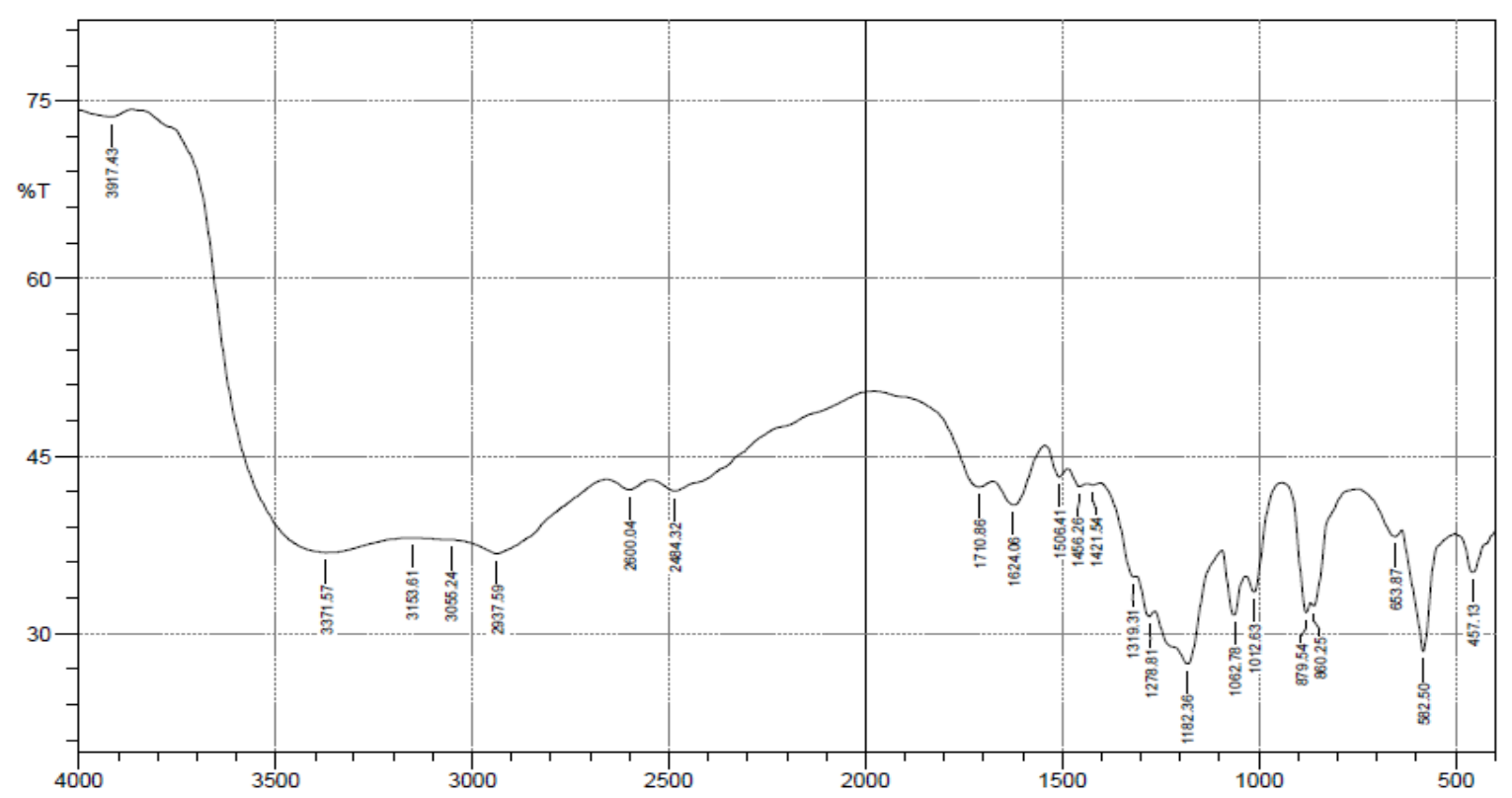

Gambar 4. Grafik FT-IR Lignin Isolat

\section{Kesimpulan}

Tandan kosong kelapa sawit (TKKS) merupakan salah satu alternatif sumber dan menambah nilai ekonomis TKKS tersebut. Rendemen lignin tertinggi yang diperoleh yaitu $16,42 \%$ yaitu pada waktu pemasakan 2 jam, konsentrasi katalis $\mathrm{NaOH} 20 \%$, dengan pengenceran lindi hitam 1:1. Terdeteksinya gugus-gugus fungsi penyusun lignin dengan menggunakan FT-IR seperti uluran $\mathrm{OH}, \mathrm{C}-\mathrm{H}$ metil, cincin aromatik, C-H asimetri, cincin stringil, cincin guasil, dan $\mathrm{C}-\mathrm{H}$ aromatik menunjukkan senyawa tersebut benar-benar lignin.

\section{Daftar Pustaka}

[1] Achmadi, S.S. Kimia Kayu. Depdikbud, Direktorat Pendidikan Tinggi, Pusat Antar Universitas Bioteknologi, IPB. 1990.

[2] Damat. Isolasi Lignin dari Larutan Sisa Pemasak Pabrik Pulp dengan menggunakan $\mathrm{H}_{2} \mathrm{SO}_{4}$ dan $\mathrm{HCl}$. Fakultas Teknologi Pertanian, IPB. 1989.

[3] Darnoko, Pembuatan Pulp dari Tandan Kosong Sawit dengan Penambahan Surfaktan. Jurnal Penelitian Kelapa Sawit. 3 (1): 75-87. 1995.

[4] DirJen Perkebunan. Statistika Perkelapa Sawitan Indonesia. Departemen Pertanian, DirJen Perkebunan Indonesia, Jakarta. 2005

[5] Fengel, D. dan G. Wegener. 1995. Kayu : Kimia, Ultrastruktur, Reaksi-Reaksi. Diterjemaahkan oleh Sastrohamidjojo, H.
Terjemahan dari : Wood : Chemical, Ultrastructure, Reactions. Gadjah Mada University Press, Yogyakarta.

[6] Hergert, H. L. 1971. Infrared Spectra. Willey Interscience, New York. 267-297.

[7] Rostika. 2002. Karakteristik Lignin Dari Limbah Pemasakan Kayu Hutan Tanaman Industri (HTI) Secara Kromatografi. Balai Besar Penelitian dan Pengembangan Industri ; Departemen Perindustrian dan Perdagangan.

[8] Sarkanen, K., V. S. Assiz and V. Chiang. 1980. Organosolv Pulping. Semi annual Report I and II. College of Forest Resources, Univ. of Washington, New York.

[9] Sjostrom, Eero. Kimia Kayu, Dasar-dasar dan Penggunaan Edisi Kedua, 1995. 